\title{
Hugo Chavez's polarizing legacy: CHAVISMo, MEdia, AND PUBLIC OPINION IN ARGENTINA'S DOMESTIC POLITICS*
}

\author{
El legado polarizador de Hugo Chávez: chavismo, medios y opinión \\ pública en la política interna Argentina
}

\author{
IÑAKI SAGARZAZU \\ Texas Tech University \\ FERNANDO MOURON \\ King's College London - Universidade de São Paulo
}

\begin{abstract}
Since Hugo Chávez Frias assumed the Venezuelan presidency in 1999, Venezuela has strengthened ties with most of its Latin American neighbors, particularly those where sympathetic leftist administrations also managed to assume power, including Argentina. With our analysis we show: 1) that Argentine media, divided between pro- and anti-government positions, presents a polarized view of chavismo; and 2) that Argentine public opinion regarding Chávez is not necessarily divided on the basis of ideological affiliations (left-right), but rather by the rejection or support of the former Argentine government. With these findings, we argue that in such a polarized information environment, chavismo is a polarizing issue and a tool that can be exploited in the domestic realm.
\end{abstract}

Key words: chavismo, Venezuela, Argentina, media, public opinion

\section{RESUMEN}

Desde la asunción de Hugo Chávez Frias a la presidencia en 1999, Venezuela estrechó vínculos con la mayoría de los países latinoamericanos, particularmente con aquellos donde también arribaron al poder administraciones con orientaciones de izquierda, incluyendo Argentina. Con este análisis demostramos que: 1) los medios argentinos, divididos en un clivaje gobierno-oposición, presentan una visión polarizada repecto al chavismo; 2) que la opinión pública argentina respecto a Chávez no está necesariamente dividida en base a afiliaciones ideológicas (izquierda-derecha), sino por rechazo o apoyo al gobierno Kirchnerista. Con estos hallazgos argumentamos que en un entorno de información polarizado la percepción que se tiene del chavismo es un tema polarizador y una herramienta que puede aprovecharse para obtener ventajas en el escenario doméstico.

Palabras clave: chavismo, Venezuela, Argentina, medios, opinión pública

\footnotetext{
The authors would like to thank Lorena Barberia, Janina Onuki, Francisco Urdinez, Pedro Feliú, Matheus Soldi Hardt, Pietro Rodrigues, Manuel Balan, the participants of the Analyzing Latin American Politics Conference (University of Houston), and the anonymous reviewers for valuable comments and suggestions. The authors' names follow the principle of rotation. Both authors have contributed equally to all work.
} 


\section{INTRODUCTION}

After winning by a landslide in Venezuela's 1998 presidential election, ${ }^{1}$ Hugo Chávez Frías not only used his victory to put an end to the puntofijista system (Levine 2002), but used his "chavismo" political brand to propel him to win in thirteen of the subsequent fourteen electoral contests during the eventual three terms of his presidency. ${ }^{2}$ Buoyed by the mandate conferred by these electoral victories and a 2002 windfall in petroleum prices for oil-rich Venezuela (see Figure 1 ), the "Bolivarian"3 president radically altered the political structure of Venezuela. These changes, in an era of high social conflict (Lander 2005), included new forms of collective action for workers (López-Maya 2002; Hawkins 2010), the inclusion of historically marginalized groups into the political, economic, and cultural life of Venezuela (Ellner 2011), and a style of government some have described as charismatic (Zúquete 2008), populist (Roberts 2006) and authoritarian (Maingon and Welsch 2009). As a consequence, all these transformations resulted in a strong polarization of the Venezuelan electorate (Ellner and Hellinger 2003). While the conditions for this environment existed in Venezuelan politics during the preChávez period (López-Maya 2003; Buxton 2005), it became an official style of government under Chávez (López-Maya and Lander 2010: 552) that continues to this day via his hand-picked successor, Nicolás Maduro (Sagarzazu 2014).

Figure 1: The price of oil, 1989-2014

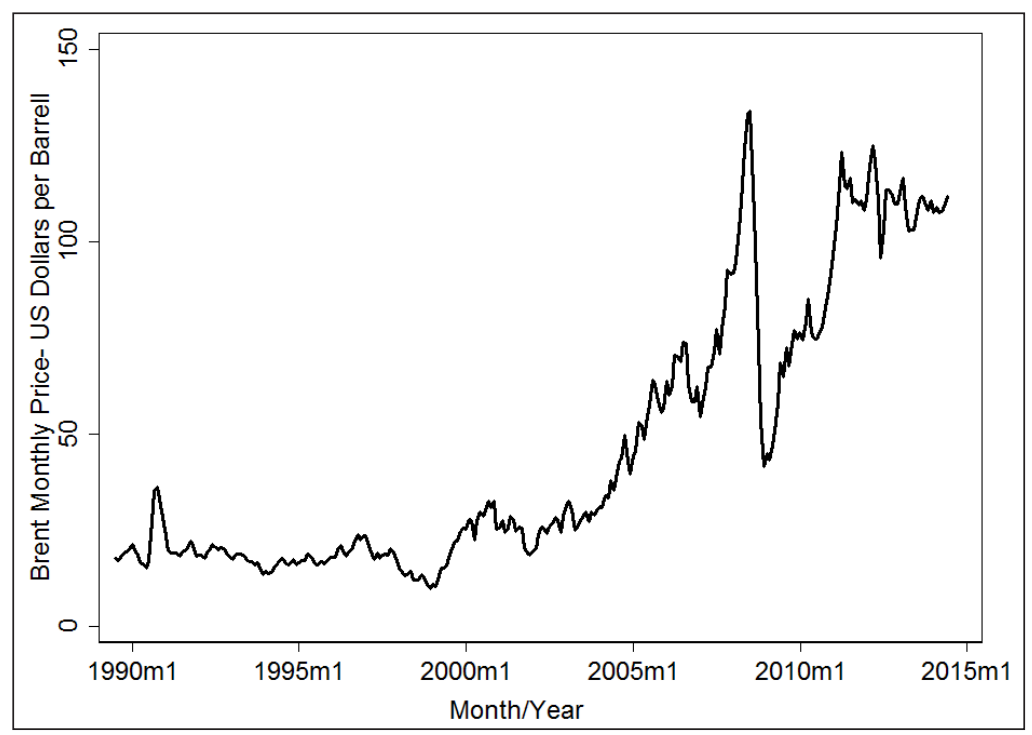

Source: United States Energy Information Administration (2017)

Chávez obtained $56.20 \%$ of the valid votes, followed by Henrique Salas Römer with just 39.97\%.

First with the alliance led by the Fifth Republic Movement (MVR), and later with the United Socialist Party of Venezuela (PSUV).

For more information about Bolivarianism, its origins and development, see López-Maya (2008). 
Since the founding the Organization of the Petroleum Exporting Countries (OPEC) in 1960, Venezuela has used oil revenue as one of the fundamental tools of its foreign policy. However, the Chávez administration relied on this money at unprecedented levels in order to realize both domestic and international political objectives (Alvarez 2007). This primarily explains how Venezuela was able to expand its influence in Latin America (Arriagada-Herrera 2006; Poertner 2011). While academic studies exist regarding Venezuela's entry and attempts to control the Latin American agenda (see for instance Serbin 2006), there have been few attempts at understanding what effect the Chávez-driven expansion has had at the domestic level in the rest of the countries in the region.

There are three important reasons for understanding Venezuela's role in Latin America. The first is recognizing the high level of polarization brought by chavismo in Venezuela itself (Ellner and Hellinger 2003; Buxton 2005; Sagarzazu 2014). The second is understanding how such polarization has spread beyond Venezuela's borders to take root elsewhere, especially in the countries that share strong bilateral relations with Caracas. In this regard we show that this polarization is independent of ideological affiliations (left-right), but due to governments' support for Chávez. For instance, as shown in Figure 2, the degree to which Latin Americans believe that Venezuela is a democracy is directly correlated with their evaluation of Chávez himself. Finally, the polemic issues of Chávez and Venezuelan democracy are directly related to the degree to which chavismo can be used to take advantage of a country's domestic politics. In Argentina's case, opposition parties have potrayed chavismo in a negative light (Kitzberger 2010a), while, for example, Luiz Inácio Lula da Silva's Brazil has been used as an "inverted mirror" in order to present a contrast between a rising Brazil and a decadent Argentina (see for instance Russell and Tokatlian 2011; Mouron et al. 2016). As such, understanding why and where this polarization exists in a country's politics is important to comprehend how foreign affairs can influence domestic debates. 
Figure 2: Pairwise regression between the degree of democracy in Venezuela and view of Chávez

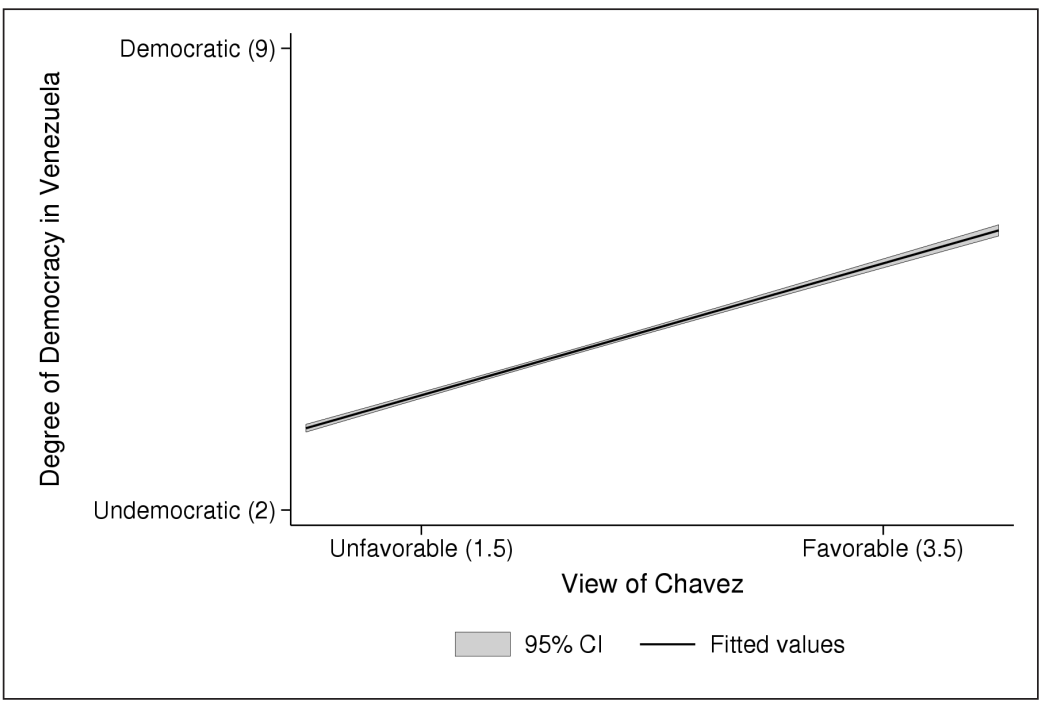

Source: Latinobarometer (2010)

The objective of this paper is to show whether Latin American countries' association with Chávez's government has become a polarizing issue in their domestic politics (Paramio 2006). The case of Argentina is a cogent example to better understand this phenomenon. Argentina's two Kirchner governments (Néstor 2003-2007 and Cristina 2007-2015) established stronger bilateral relations with Caracas. As the two countries' governments have grown closer, so too has Argentine society used this relationship as a mechanism to criticize their former administration and some of its policies. Given this reality, we attempt to provide some insight into the dynamics of news production and of public opinion as it relates to Argentine foreign affairs. We carry out our study by employing a quantitative analysis of the Argentinian media and two public opinion surveys.

Our paper is structured as follows. First, we contextualize the bilateral relations between Argentina and Venezuela throughout the last ten years, paying special attention to stringent policies affecting the independence of news media. Secondly, we describe the construction of our database, explaining how we calculated models and results from our quantitative text analysis using Venezuelan media stories from two of the most important Argentinian newspapers. Later, we strengthen the connection between the media and public opinion by employing two public opinion surveys: one is an original study we conducted at the Universidad de Buenos Aires, and the other is from the Latinobarometer polling institution. Our conclusion debates the extent to which the preponderance of chavismo in a country's domestic politics is an Argentinespecific issue or whether the conditions exist for it to be found elsewhere. 


\section{VENEZUELA \& ARGENTINA: A RELATIONSHIP UNPRECEDENTED IN CLOSENESS?}

In the past ten years, Argentina and Venezuela have deepened their bilateral relations to an unprecedented level. The following analysis explains such a partnership through the lens of structural economic factors as well as political decisions.

According to the Argentine Ministry of Economy, total trade between Caracas and Buenos Aires grew at a rate of 36.6\% per year between 2002 and 2010 (MECON, 2011). Indeed, Argentina's exports to Venezuela increased at an annual rate of $32.7 \%$, while its Venezuelan imports grew at a rate of $14.4 \%$. Such an increase in trade must primarily be explained by the favorable trade needs between the two economies. Indeed, Argentina is abundant in food and food byproducts, and Venezuela is a net importer of these products. The convenience of these trading partners can be explained further: milk and its byproducts, meat, meat offal, fats, and animal and vegetable oils accounted for $34.9 \%$ of Argentine exports to Venezuela in 2010, an amount that has remained steady due to Venezuela's single product economy.

During these years, the economic model adopted by Néstor Kirchner and followed by Cristina Fernández de Kirchner had been based on a strong proliferation of Argentine consumption mixed with subsidies for basic services, ${ }^{5}$ an approach that has greatly increased Argentine consumption of energy. In order for the former administration to meet this demand, the easiest alternative was to import more fossil fuels to power thermoelectric plants. Given that the Venezuelan economy is primarily based on the production and export of oil and chemical derivatives, agreements between the two countries have naturally increased during the last decade. ${ }^{6}$ Other examples of this relationship abound. Since 2005, and after the first restructuring of the defaulted debt, Argentina financed its debt maturities with bonds issued to the Venezuelan government at rates lower than those charged by the international markets but higher than those charged by multilateral agencies like the IMF (Bonvecchi and Giraudy 2007: 33).

Moving to a more political analysis, since their rejection of traditional neoliberal projects like the Free Trade Agreement of the Americas (FTAA) in 2005, the previous occupants of Argentine's Casa Rosada and Venezuela's Palacio de

$4 \quad$ According to data provided by the Venezuelan National Institute of Statistics, Venezuela imported in $\$ 8.12$ billion USD in food and articles derived from the food industry in 2012.

5 For more information see the Argentine 2013 budget http://www.mecon.gov.ar/onp/html/presupresumen/resum13.pdf

6 To see all the agreements signed between the two countries, see http://argentina.embajada.gob.ve/index. php?option $=$ com_content\&id=66\&Itemid $=29$

Negotiations for the signature of the FTAA included Latin American countries (excpet Cuba) and the United States began in 1994 with the first Summit of the Americas. However, at the fourth Summit, held in Mar del Plata during September 2005, the agreement was rejected and negotiations ended due to the strong opposition posed by Latin America's leftist leaders in power at the time. 
Miraflores increasingly engaged in a bilateral relationship marked by affinity and mutual support. This closer relationship is not unique to Venezuela and Argentina, but rather a leftist "pink tide" that swept throughout Latin America in recent years. This uptick of leftist leaders in presidential palaces throughout the region spurred several comparative analysis of these movements (Petkoff 2005; Castañeda 2006; Levitsky and Murillo 2008).

Two studies by the former cabinet ministers of Venezuela and Mexico, Teodoro Petkoff and Jorge Castañeda, respectively, highlight some of the differences between these leftist movements. Petkoff (2005) was the first to suggest that the movements should not be considered homogeneous. In a similar vein, Castañeda (2006) proposed describing the new governments as belonging to two different types of "left": one that adopts a modern, open-minded, reformist and internationalist stance, and another that is the heir to the populist tradition, more insular and nationalist. Argentina (utill the end of 2015) and Venezuela would fall in the second category, as Kirchner and Chávez showed little interest in prioritizing economic performance, democratic values, programmatic achievements, and kindling good relations with the United States (Castañeda 2006).

However, for Levitsky and Murillo (2008), the fact that countries have tightened their bilateral relations does not necessarily imply that Kirchnerism and chavismo, should be considered as synonymous. In the authors' words, strong democratic institutions, a strong civil society, and the nature of his own Peronist coalition limited Néstor Kirchner's ability to concentrate power. Thus, Argentina never approached the centralized and autocratic posture that became a staple of the Chávez years, even at the height of Kirchner's popularity and political strength (Levitsky and Murillo 2008: 83).

Given their similarities, however, both countries' political postures have been compared in recent years. During the 2007 Argentine presidential campaign, a Venezuelan official named Antonini Wilson was caught at the Buenos Aires airport with a suitcase containing 800,000 USD. Although Wilson initially declared that the money would be used to finance Cristina Kirchner's campaign, the United States Department of Justice issued a statement claiming that the suitcase was not from Antonini, but rather another unnamed passenger. While no campaign finance malfeasance was ever proven, another event raised even more questions. At the same time as the Wilson scandal, three Venezuelan officers were convicted of concealment, so suspicions of Chávez funding Cristina's campaign lingered (Bonvecchi and Giraudy 2008: 45-46). On the heels of the negative press from this event, one year later Cristina carried out a media reform under the stigma of "venezuelization," a pejorative term in the Latin American context (Kitzberger 2010a: 11). Indeed, both movements were consistently associated until the end of Cristina's administration, mainly in a negative sense. In the next section we look in more detail at the evolution of the relationship between the Argentinian government and media. 


\section{Media as a Political Voice}

During the last decade, several mostly leftist Latin American governments have tried to introduce reforms to their countries' media systems (Kitzberger 2009, 2010b; Waisbord 2011). Numerous factors explain these initiatives: first, the media play a key political role in most Latin American democracies (Ruiz 2010); second, the tight ideological makeup of most media organizations, mostly dominated by conservatives (O'Schaughnessy 2007; Becerra and Mastrini 2009); and finally, the sometimes openly subversive role conservative media has played in supporting the removal of democratic governments (Cannon 2004).

In the Argentine case, the pro-media policies implemented by Menem's administration (1989-1999) fostered a more conducive atmosphere for the creation of media congolomerates (Belinche 2004). Nestor Kirchner's administration did not structurally change these policies. In fact, former president Kirchner decided to extend media licenses for ten years, and even approved the merger of the two largest cable providers (Cablevision and Multicanal). As such, instead of making any structural changes, Kirchner took a more confrontational tone against the biggest media groups (Vincent 2011).

Since the beginning of Cristina Fernandez's administration (2007-2015), however, the Argentine government has taken a more antagonistic, even radical approach to the press (Kitzberger 2010a). During this time, Argentina experienced a deepening level of social polarization that had not existed since the early period of Peronism (De Luca and Malamud 2010: 174). The problems began during the approval process of the so-called Resolution 125 (Frajman 2014). With this measure, the government attempted to change the taxation system for agricultural exports, establishing a progressive taxation mechanism indexed to international commodity prices. ${ }^{8}$ This resolution proved to be very divisive in Argentinian society, generating a conflict between the government and agricultural producers. During this clash, Grupo Clarín, the largest media conglomerate in Argentina, dedicated significant coverage to the most controversial aspects of the project, blaming the government for the conflict (Zunino and Aruguete 2010). Subsequently, after failing to approve the bill, Casa Rosada chalked the legislative defeat down to a problem with their communication strategy rather than a structural flaw in the design of the resolution. Consequently, the Executive sent Congress a measure to reform the media (for a detailed description of the conflict, see MacRory 2013), which passed after bitter a dispute (Catterberg and Palanza 2012: 9). In just a few months, the proposal managed to segment a previously ideological left-right media system into pro- and anti-government factions. As previously mentioned, it was during this time that traditional media criticized the situation with the pejorative "venezuelanización" or "chavización". In the following section we

8 For more information see http://infoleg.mecon.gov.ar/infolegInternet/anexos/135000-139999/138567/ texact.htm. 
show how the two main Argentine newspapers used the shadow of Venezuela to frame the country's political debates.

\section{A POLARIZED PRESS}

In this section, we analyze the frequency and tone with which the Argentine press reported on Venezuelan politics. To do so we rely on a quantitative text analysis technique (Wordfish, develop by Slapin and Proksch (2008)) that, via scaling procedures, positions the data on a continuum based on the similarity of texts with each other. We first explain the construction of the dataset for analysis. We then discuss how the two newspapers in the study differed in their coverage of Venezuela, as evidenced by the results of our content analysis.

\section{The Data}

In order to test the argument made in the previous section we need to evaluate the degree to which the Argentine media's stories about Venezuela have a political bias based on the newspaper where they are published. We chose La Nación and Página 12 based on data availability and official circulation numbers. ${ }^{9}$ From a circulation standpoint, these are two of the most widely read newspapers in Argentina, ${ }^{10}$ but, more importantly, have opposite ideological inclinations, with Página 12 supporting the former government and La Nación supporting the opposition at the time (Balán 2013). ${ }^{11}$ Our data provide a great opportunity to evaluate how these newspapers differ in their respective representations of international affairs.

We studied the frequency with which Argentinian newspapers discussed Venezuela from 2009 to 2013 . We chose to begin our study on the day that Law 26.522 (Audiovisual Communication Services Law) was enacted and end four years later. This period encompasses a sufficiently long span that it is unlikely to be biased by any temporary partisan issues that could have occurred with a smaller sample size. Moreover, if in this time period, we are able to find a consistent bias in the Venezuela reporting, then that would support our argument that that country's image is used as a wedge to shape domestic debate. Of the newspaper articles in our study, we paid most attention to those focusing primarily on Venezuela, but also chose stories reporting on news in the

9 La Nación is the second most read newspaper with a circulation of 165,000 papers a day, while Página 12 has a daily circulation of 51,000 newspapers according to the Cultural Information System of Argentina http:/ / sinca.cultura.gov.ar/sic/estadisticas/.

10 While it would have been ideal to also include Clarín, the most read newspaper, in the analysis, its print version is not isolated from its online version, which made it impossible to create a database similar to the other two sources.

11 As it has been shown previously, the government-opposition divide can structure a country's political realm (Alemán et al. 2011; Jones, Hwang and Micozzi 2009). 
country and its bilateral relations. ${ }^{12}$ We excluded articles about the arts, sports, or others mentioning Venezuela only in passing, such as its participation in an article primarily dominated on international organizations.

All together, we analyzed 1,492 print edition articles. Of these, 1,004 were published by La Nación, and 488 were published by Página $12 .{ }^{13}$ While we acknowledge the disparity between the sizes of both samples, the discrepancy in justified by the fact that La Nación is a larger publication.

\section{Scaling Newspaper Articles}

In order to measure the newspaper articles' pro- or anti- Chávez sentiment we used Wordfish, a quantitative text analysis technique (Proksch and Slapin 2008; Slapin and Proksch 2008). This procedure, which uses the co-occurrences of different words in each text, generates a classification of the texts based on the frequencies with which the articles mentioned different words. Specifically, this scale ranks the articles by interpreting the different texts based on how similarly they use different words. For example, two texts that use the same words approximately the same number of times will be located closer to each other than two texts that use different words. As such, newspaper articles are automatically placed on a continuum. This procedure allowed us to create a text-to-text comparison and align the articles on a scale. While this technique has been most promiently used for identifying ideological scales, the only limit to its use is the existance of an underlying dimension in the texts under analysis, in our case that dimension is pro- or anti-Chávez rethoric.

The advantages of applying this method to our newspaper dataset are that it allows for a completely replicable analysis, and that it permits the analysis of large volumes of data without needing reference texts or values. The major drawback is the possibility of questioning the results' validity. However, as we are cognizant of this, we performed a validity analysis once our documents were classified.

The input for this algorithm are the newspaper articles. However, before similarities can be established and a scale generated, these need to be preprocessed. Following standard procedures in the text analysis literature (see, for instance, Grimmer 2010; Grimmer and Stewart 2013; Sagarzazu and Klüver 2015) we removed puntuation, numbers, and capitalization from the texts. We reduced the dimensionality of the data by converting all words to their sintactical root (stem) and by eliminating words present in less than $1 \%$ of the articles. Once the texts were pre-processed, we converted them to a document term matrix, where each column is a term $s$, each row is a document $d$, and each

In that sense, we only included articles that mentioned Venezuela in their title or subtitle.

We only included print media and not other media outlets (such as the TV) given the intra-media agenda setting influence that the printed media has on TV news shows (Vliegenthart and Walgrave 2008). 
cell $c_{s d}$ is the number of times term $s$ was mentioned in document $d$. This matrix is the input to our Wordfish algorithm.

Once the algorithm is executed and the results estimated, we can find out which words help classify the documents on the scale, which is a definitive advantage of the algorithm. Each word has a weight assigned based on its usage in the texts and in comparison to the other words. The program uses this value to classify the position of articles that use the word. For us, words with most negative and positive values were the most useful in discerning bias between the articles. In the case of our dataset, we found that articles with negative scores tended to be defined by words such as "bribe", "inflation", "debt", or "nationalization", while articles with a positive score included words such as "prayer", "listens", "brother", "love", or "youth (see Figure 3). Based on these results, we are confident that the words classifying the newspaper articles indicate some form of positive or negative coverage of Venezuela.

Figure 3. Wordfish classification of words for classifying documents.

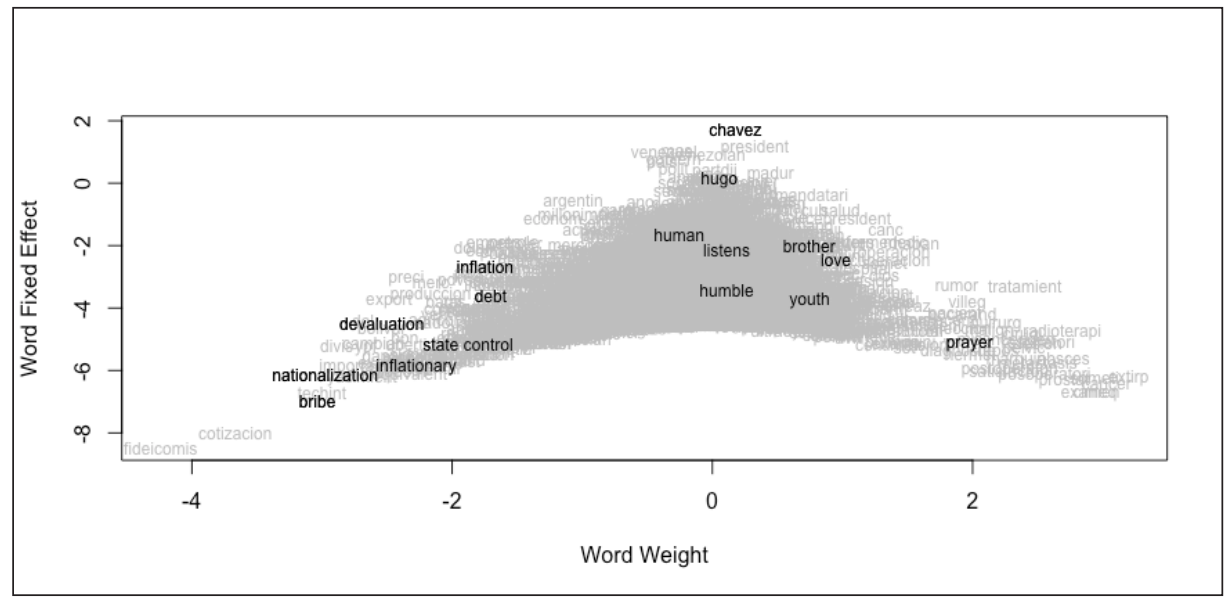

Using the estimated coefficients for the different words, Wordfish generates evaluations of the different texts taking into account the word frequencies that appear in each text. This score assigns documents to a scale based on their similarity; as such, two documents that are close together will have similar word frequency patterns, while documents that are farther apart will be more different. Figure 4 shows the distribution of articles using the estimated weight. As one can see, the documents are organized along an Anti-Pro Chávez continuum (with negative numbers being anti-chávez and positive values being pro-chávez). 
Figure 4: Document position estimates vs. document fixed effects

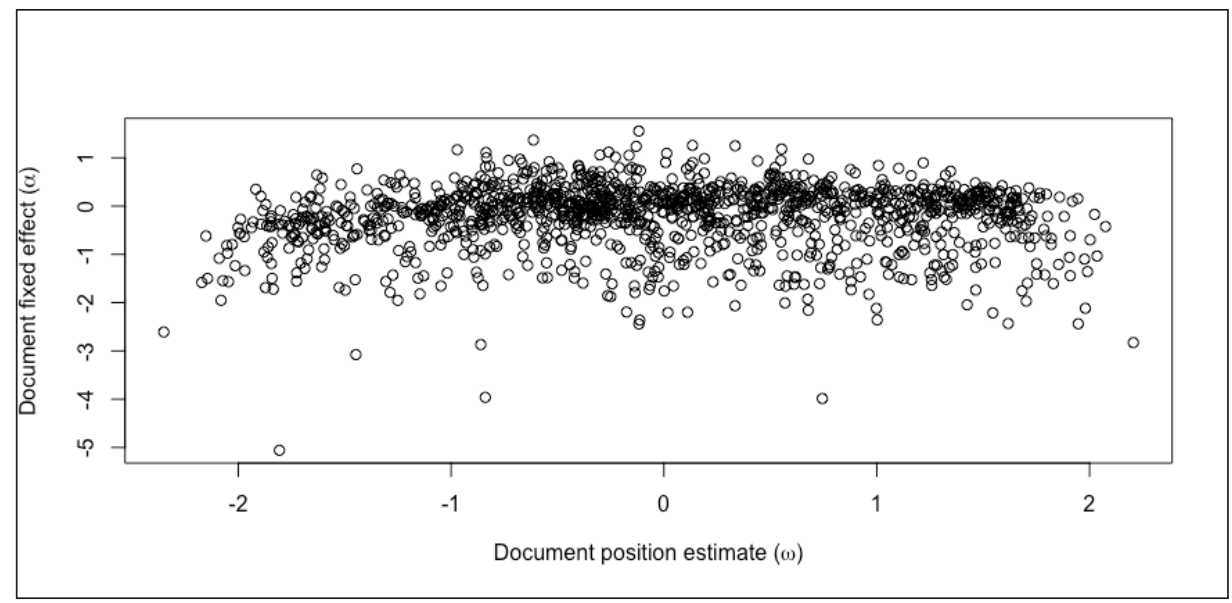

As mentioned before, while the tool we chose is reliable, its validity needs to be asserted. That is, we needed to make sure that the scale measured a tangible positive or negative score for the coverage of the Venezuelan government. We had partly achieved this with the analysis of the word scores presented above. However, in order to be certain that our main points are effectively measuring a bias in Venezuelan news, we performed several tests.

First, we checked that the time series nature of our dataset did not distort the estimates by accidently identifying changing linguistic usage over time instead of a political slant. To test this, we regressed our estimates based on the date of the article's publication and found that there is no relationship between these two variables (the coefficient for the date variable is 0.0006). On the contrary, an article's ideal points were evenly distributed through time. ${ }^{14}$ Second, we selected a random sample of the articles. This random sample was coded blindly by two independent coders who placed documents on a five-point scale ranging from -2 to $2{ }^{15}$ This classification was first compared between coders to guarantee its reliability (which, according to Hughes and Garrett (1990), is very reliable: see results in Appendix D). The second step was to create the average measure for cases of disagreements between coders, which was compared to our Wordfish estimates. Based on this comparison (with a positive and significant coefficient) we are confident that our quantitative text analysis scores provide a good measure of positivity/negativity against Chávez. Finally, we selected examples of how La Nación and Página 12 framed chavismo in a negative and positive way, respectevily (see Appendix B). From that analysis, we can observe that in the case of La Nación, the editorial line tried to compare both administrations in a

See Figure 1 and Table 1 in Appendix A.

Very negative (-2), negative (-1), neutral (0), positive (1), very positive (2). 
negative way, using terms such as "venezuelanización" and "chavización", but also explicitly stating that the Argentinian government was imitating its Venezuelan counterpart. On the contrary, Página 12 presented chavismo as a good example, while highlighting how the bilateral relationship was positive for the country, and the fact that Venezuela was one of the few reliable partners that helped Argentina after the country defaulted in 2002.

\section{A Polarized Press?}

Having estimated and checked the validity of our article classification on a positive or negative scale, we proceeded to evaluate whether the articles from these two media outlets have a political slant. To do so, we first evaluated the distribution of the classified documents. Figure 5 shows the distribution of articles for La Nación (solid line) and Página 12 (dotted line) along our negative/positive scale. It is clear from the two lines shown that the articles from La Nación are defined as more "negative" than those of Página 12-that is, there are more negative stories about Venezuela in the former, and more positive ones in the latter.

Figure 5: Distribution of articles on a pro/anti-Chávez scale by newspaper

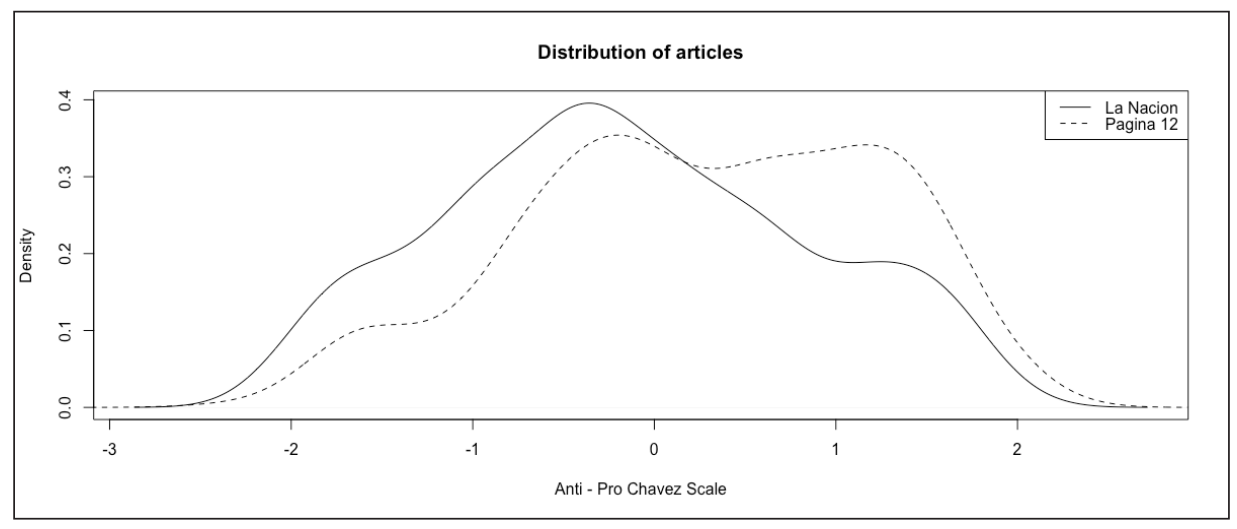

However, in order to be certain of this distinction we compared both samples by using a two-sample t-test. This type of test is appropriate when comparing two populations in order to determine whether the two are significantly different from each other. As Table 1 shows, the means of both samples are different; this is statistically significant at the $99 \%$ confidence level. This finding corroborates the visual representation of the data in Figure 4, that articles published in $\mathrm{La}$ Nación are more negative toward Venezuela than those published in Página $12 .{ }^{16}$

16 The quantitative text analysis provides a more conservative estimate of newspaper article location than the hand-coded sample. Appendix D shows that for the hand-coded sample the mean of La Nación articles is -1 and the mean of Página 12 articles is 0.96 . 
Table 1: Two sample t-test with equal variance

\begin{tabular}{ccccccc}
\hline Newspaper & Obs & Mean & Std. Err. & Std. Dev. & \multicolumn{2}{c}{$95 \%$ Conf. Interval } \\
\hline La Nación & 846 & -0.1553 & 0.0339 & 0.9888 & -0.222 & -0.088 \\
Página 12 & 492 & 0.2671 & 0.0434 & 0.9628 & 0.182 & 0.352 \\
Combined & 1338 & $1.2 \mathrm{e}-09$ & 0.0273 & 1 & -0.053 & 0.0536 \\
Difference & & -0.4224 & 0.0555 & & -0.531 & -0.313 \\
\hline
\end{tabular}

After identifying that in Argentina mass media presents a divergent vision about chavismo, it was time to ask ourselves how this representation has affected public opinion perceptions on this issue.

\section{THE OTHER SIDE OF THE COIN: ARGENTINIAN PUBLIC OPINION PERCEPTIONS}

The relationship between media and public opinion is a longstanding and wellstudied phenomenon (McCombs and Shaw 1972; McCombs 2013). Although the direction of causality is disputed, there is no doubt that mass media is a key agent for the formation of public opinion (Corner 2007: 212). Previous studies have shown that what people believe are the most relevant topics on the political agenda, are at the same time the ones that gained visibility in the mass media (Wanta and Ghanem 2007). Moreover, through an empirical analysis, D'Adamo et al. (2000) have found that, for the Argentinean case, mass media has a strong influence on public opinion and the political agenda.

Related to our subject of study, we can affirm that the power of mass media is much stronger on public opinion perceptions regarding foreign issues (Wanta et al. 2004). This can be explained by two main reasons. On the one hand, the average citizen has less interest in foreign affairs compared to domestic ones, which makes prior perceptions more volatile and sensitive to new pieces of information (Mueller 2002). On the other, as most of the citizens do not have direct contact with what happens abroad (Soroka 2003: 8), this endows mass media with a gatekeeping role regarding foreign issues (Hill 2003: 275). In the end, what is published by mass media is the only source of information from which most of the population gets their information about foreign affairs (Puglisi and Snyder 2008: 3), which also explains why, in countries where the media is more concerned about international affairs, the knowledge of the general population is also much higher in this area (Curran et al. 2009).

Thus, in order to test whether the Argentine media's polarization of chavismo is reflected in public opinion perceptions, we carried out a survey one month after the study period of the newspaper articles ended. Our data comes from a public opinion poll conducted by the Universidad de Buenos Aires (UBA) between 
7 and 11 November 2013. This survey was administered to a convenience sample $^{17}$ of 1,006 students from the Law School (30.3\%), Economics (34.3\%) and Social Sciences (35.4\%) faculties. With help from the University's staff, we first contacted all the professors of the three faculties by email. After receiving their approval to participate, we arranged a time in which we could interrupt their lessons and apply the survey. We informed the students that they were part of a voluntary public opinion poll and as an incentive we offered a \$1,000 ARS book voucher prize. The survey was on paper and self-administered, however, we used three research assistants to avoid contagion effects.

After answering 25 questions that sought to measure perceptions of international trade, participants had to give their opinion about chavismo. Specifically, they were asked if they believed that the Argentine government was using chavismo as a reference point for its own governance (questions 1 and 2 in Appendix C). After a series of socieconomic and political questions, participants were then asked about their current political affiliation to the Argentinian government. Interviewees had to say if they considered themselves "Kirchneristas" or "Opositores", and their degree of partisanship to this attachment ${ }^{18}$ (questions 3 and 4 in Appendix C).

\section{It's All about Government Perception}

Having described our survey and a some of the aggregate measures, we now present the interaction between the main variables of our study: "government perception" and the outputs, "chavismo's image" and "chavismo as an example".

As we can see in Table 2, almost all self-described opponents of Kirchnerism have a negative view of chavismo (94\%), contrary to Kirchneristas, of whom the majority reported holding a positive view of the Venezuelan government at the time $(68 \%)$.

17 Although latent limitations, in some cases students samples have been demonstrated to work as microcosms of general public opinion (Druckman and Kam 2011). Moreover, they provide an efficient way to test initial hypotheses before attempting to generalize one's theory to broader samples (Dasgupta and Hunsinger 2008).

18 Before applying the definitive questionnaire to the whole sample, we carried out a pilot study with a smaller sample of 50 students. From this preliminary version we perceived that it made no sense to use a 5 points scale in order to capture students' perception of government, as less than $10 \%$ of respondents did have a position regarding Kirchner's administration. As a consequence, and because the survey was self-administered, we gave participants the possibility to leave some comments through an open-ended answer option. In this sense, just $1.89 \%$ expressed that they felt themselves neither Kirchneristas nor opposition. 
Table 2: Predicted probit coefficients (95\% confidence intervals)

\begin{tabular}{cccc}
\hline & & \multicolumn{2}{c}{ Government perception } \\
\cline { 3 - 4 } & & Opponents & Kirchneristas \\
\hline & Negative & $94 \%$ & $32 \%$ \\
Image of chavismo & $(92-97 \%)$ & $(28-36 \%)$ \\
(opinion) & Positive & $6 \%$ & $68 \%$ \\
& & $(3-8 \%)$ & $(64-72 \%)$ \\
[Argentinian Government] Uses & No & $30 \%$ & $64.5 \%$ \\
chavista model as example? & & $(26-35 \%)$ & $(60-68 \%)$ \\
(reference) & Yes & $70 \%$ & $35.5 \%$ \\
& & $(65-74 \%)$ & $(32-39 \%)$ \\
\hline
\end{tabular}

* $63.23 \%$ of the students declared approval of the Kirchner's administration, while $36.77 \%$ stated that they dissaproved the former Argentine government.

Our findings confirm the hypothesis that the opposition in Argentina tends to view both the Argentine and Venezuelan political entities in a negative light. Of the interviewees that self-identified as being against the Argentine government, $70 \%$ also believed that Kirchnerism uses chavismo as a model. On the other hand, just $35.5 \%$ supporters agreed with that statement, and of those $44 \%$ had a positive view of Venezuelan government. Consequently, we can affirm that just $20 \%$ of Kirchneristas think that the Argentinian government uses chavismo as a model, use the term as a negative descriptor. This finding is in itself interesting and shows that while Kirchneristas are, for the most part, supportive of Venezuela, this is not a solid block. Unlike the opposition, where views on Venezuela and Chavism are more cohesive, the Kirchneristas differed in their views, and as such this opens up the space for the politics of Venezuela to be used as a wedge issue, as described by (Sagarzazu and Mouron, 2017). 
Table 3: Results of probit regressions

\begin{tabular}{lcc}
\hline & Reference & Opinion \\
\hline Degree of support for Kirchnerism & $-0.421^{* * *}$ & $1.015^{* * *}$ \\
& $(0.043)$ & $(0.063)$ \\
Ideology & $-0.098^{* * *}$ & $0.186^{* * *}$ \\
& $(0.022)$ & $(0.026)$ \\
Age & 0.010 & 0.004 \\
& $(0.009)$ & $(0.010)$ \\
Female & $-0.432^{* * *}$ & 0.112 \\
& $(0.089)$ & $(0.104)$ \\
Part-time worker & 0.052 & -0.021 \\
& $(0.101)$ & $(0.118)$ \\
Constant & $1.546^{* * *}$ & $-4.115^{* * *}$ \\
& $(0.250)$ & $(0.336)$ \\
N & 952 & 967 \\
LogLik & -569 & -405 \\
\hline
\end{tabular}

Moreover, if we take into account the degree to which respondents identified themselves as Kirchneristas or opponents, then we can divide our sample along a four-point scale ranging from very intense opponent (1) to very intense Kirchnerist (4). Table 3 shows the coefficients from the probit regression that takes into account this intensity variable, together with controls for age, gender, ideology, and students who work while they study (versus those who do not do it). As can be seen, there are two models: reference and opinion. For the reference model, we use as the dependent variable whether the respondent thinks the Kirchner government uses Chávez as an example (1) or not (0). The dependent variable for the opinion model is whether the respondent has a good (1) or bad (0) perception of Chávez.

As the table shows, the coefficients for "intensity" (Degree of support for Kirchnerism) are statistically significant. In the model evaluating the degree to which Argentina is influenced by chavismo (reference), the coefficient is negative, indicating that opponents see more similarity between chavismo and Kirchnerism, while Kirchnerists see less. In the second model (opinion), we see that the coefficient for intensity is positive, indicating that opponents have a more negative view of chavismo. 
Figure 6: Probability of believing that Argentina follows the chavista model \& negative view of chavista model

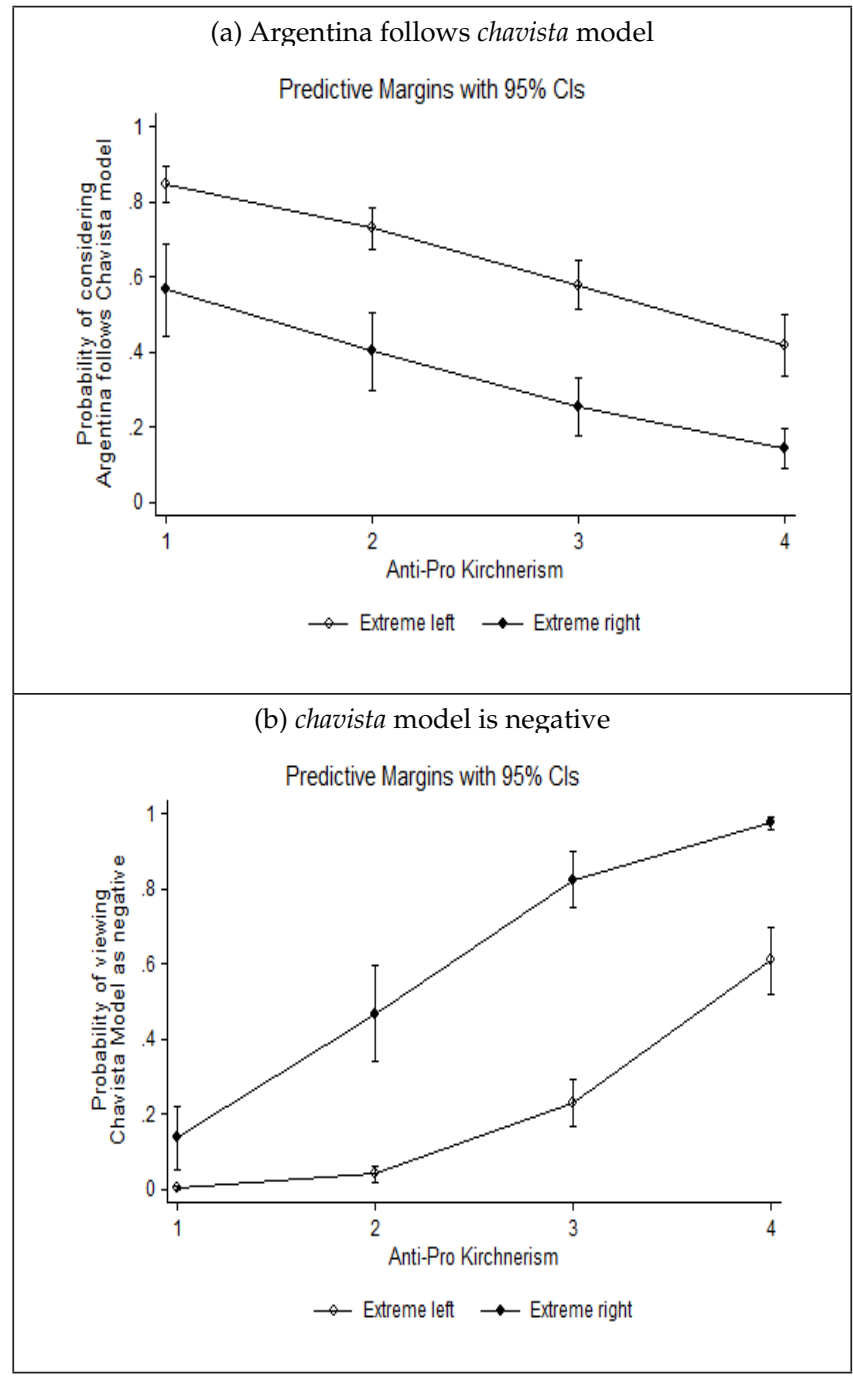

As we can see in Table 3, when controlling for variables such as political ideology, age, gender, and part-time job status, the effect continues to be statistically significant. This is particularly true when we look at the differences between the two ideological extremes. As Figures $6 \mathrm{a}$ and $6 \mathrm{~b}$ show, the lines for the most extreme self-identified left and right followers never cross, and in fact these move relatively parallel to each other. This means that respondents' perceptions of chavismo are based on support of the former government, regardless of their political ideology. Considering this new measure we can see that the effects of "government perception" are even more intense. 
Having tested the degree to which government support affects perceptions of Chávez and the belief that the Argentinian government used to follow the Chavista model, we proceeded to use a national sample to do a similar analysis. Specifically, using data from the 2010 wave of the Latinobarometer survey we tested the degree to which our results from the student sample were reflected in a representative sample of the population. For the respondents of the Argentine questionnaire, we looked at three questions. First we noted respones for the evaluation of Hugo Chávez on a four point scale from (1) very unfavorable to (4) very favourable. Second, the degree to which the respondent believed Venezuela was (1) totally undemocratic or (10) totally democratic. Finally, we looked at whether respondents supported the former Argentinian government. ${ }^{19}$

Figure 7 shows the mean value of both the Chávez (7a) and Venezuelan democracy $(7 b)$ evaluation variables and their $95 \%$ confidence intervals. These means were divided using the government support variable. As such, we can make two statements: first, similar to the student survey, former pro-government respondents evaluated both Chávez and Venezuelan democracy more positively than opponents; second, this difference is statistically significant.

Finally, if we consider only those respondents living in Buenos Aires, where the selected media have greater impact due to their rates of sales, we find that the difference between positive and negative interpretations of Chávez was even wider (Figure 8a). However this difference only exists because Buenos Aires's opponents of the Kirchner government appeared to be more partisan in their beliefs of Chávez than in the rest of the country. Interestingly enough, this difference does not extend to the evaluation of Venezuela as a whole (see Figure $8 \mathrm{~b}$ ), where respondents in Buenos Aires answered similarly to those in the rest of the country. 
Figure 7: Evaluation of Hugo Chávez and Venezuelan democracy in Argentina based on support for the national government

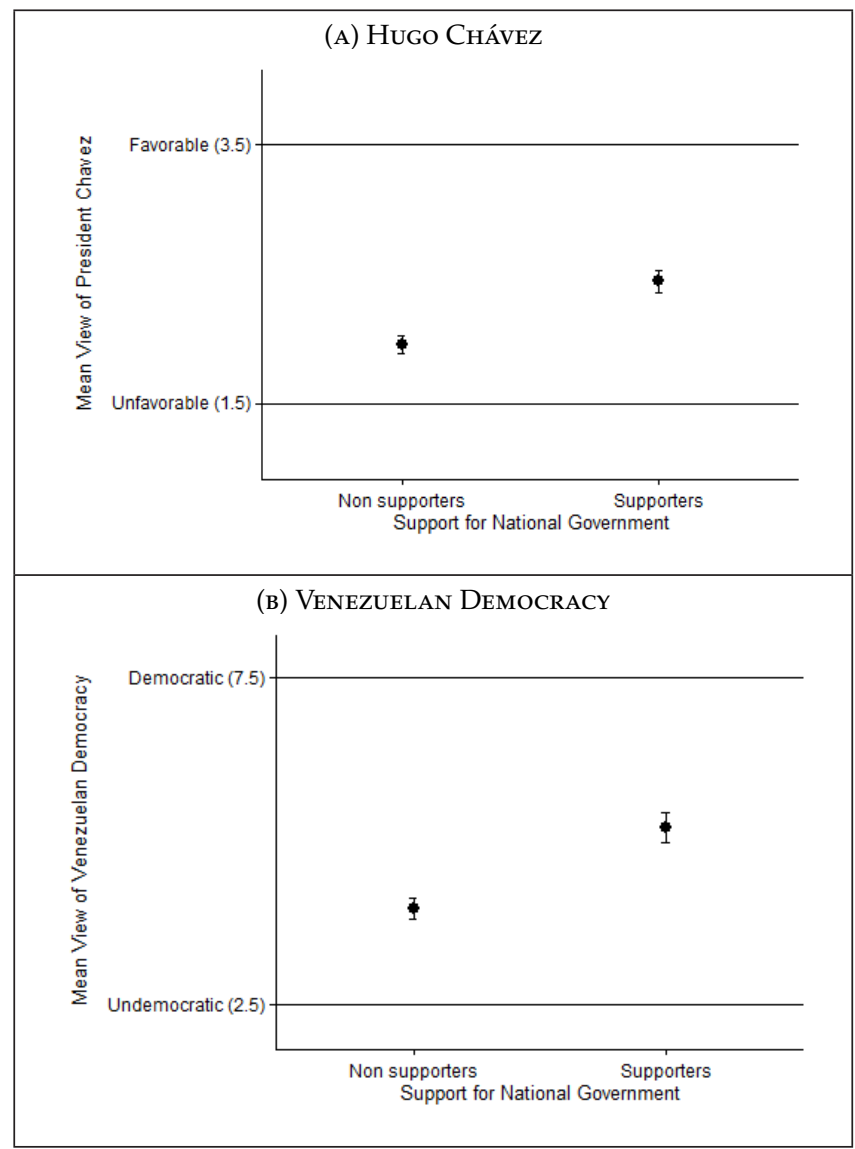

Source: Latinobarometer 2010 
Figure 8: Evaluation of Hugo Chávez and Venezuelan democracy in Buenos Aires based on support for the national government

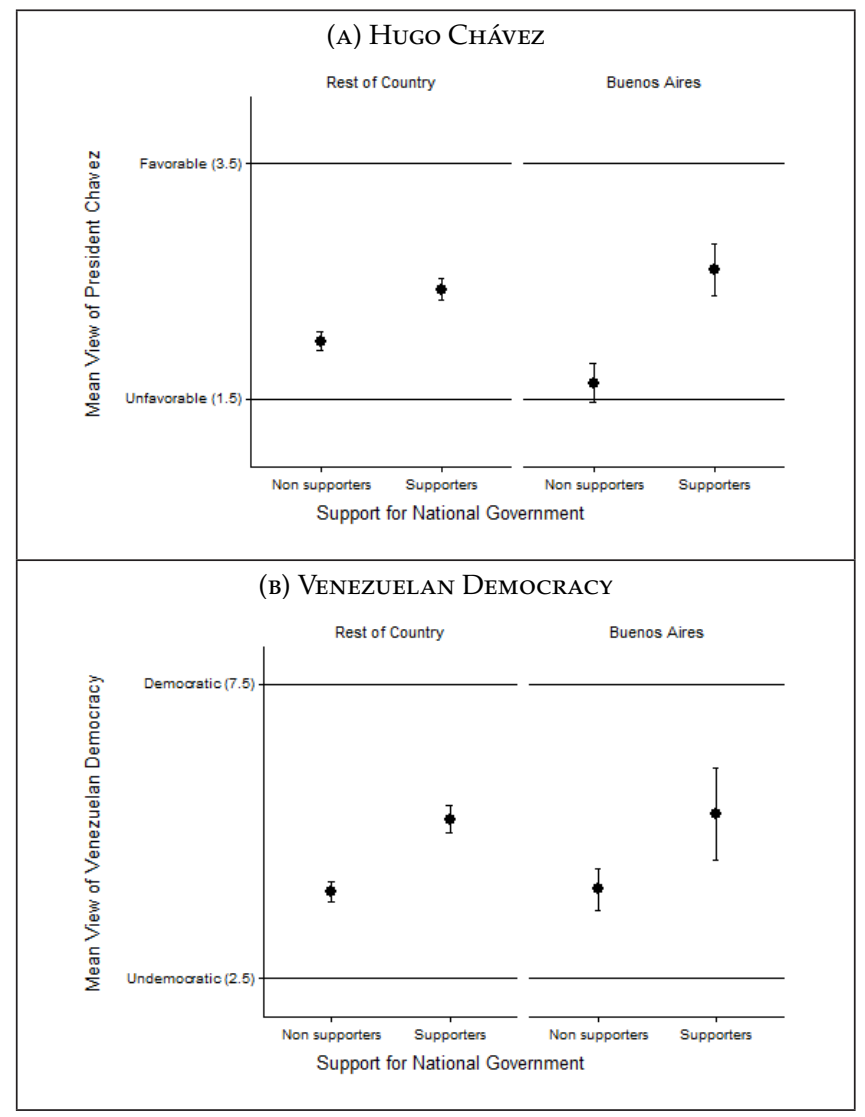

Source: Latinobarometer 2010

\section{CONCLUSIONS}

Buoyed by increasing oil revenues during the Chávez era, Venezuela made significant changes to its foreign policy. This led the Chávez government to seek stronger ties with its Latin American neighbors while forming strategic alliances with anti-establishment countries. Many of these allies emerged from governments that shared an ideological affinity with the leftist "Bolivarian Revolution", as in Argentina during the Nestor and Cristina Kirchner administrations. These close ties involved increasing commercial relationships which benefited both countries. However, until now we did not know how the increased economic and political ties impacted the domestic political debates of other countries. 
We started this paper with the objective of showing the degree to which Venezuela and Chávez existed as a divisive issue in Argentine media, and how the image displayed could affect public opinion perceptions on this issue. To do so we carried out a two-part analysis: first, we used the Argentine media to conduct a quantitative text analysis; next we studied two public opinion surveys. In both sections we find that both the Argentine media and public were divided in their views and evaluations of Venezuela and its former leader. Moreover, this split was amplified based on respondents' relationship to their national government. That is, media and citizens who supported the former government had a more positive view of Chávez and Venezuelan democracy. This comes in contrast to Kirchner's opponents, who had a negative view of both and tended to believe that chavismo is a bad example that was being followed by Argentina.

These findings raise several normative questions about the extent to which external political movements in other countries can be used to shape a country's domestic political debate. First, it is worth asking whether this polarization affects all countries similarly or whether it does so in different extents. For instance, does a culture of polarization already need to exist in a country for these dynamics to play a role? Do variables such as economic interdependence and ideological affinity alone explain this pattern? Second, if opponents of domestic chavismo sympathizers view the Venezuelan model as a bad example, they must also contrast this with "good examples, such as Brazil (see for instance Russell and Tokatlian 2011; Mouron, Urdinez and Onuki 2016). Finally, one wonders if Chávez's death has affected Venezuela's influence on other countries, especially in those where opinion of the former leader was highly respected. Future research should try to answer these questions, as chavismo became one of the most relevant phenomena in the Latin American arena in the last decade.

\section{REFERENCES}

Alemán, Eduardo, Aldo Ponce and Iñaki Sagarzazu. 2011. “Legislative Parties in Volatile Non-Programmatic Party Systems: The Peruvian Congress in Comparative Perspective". Latin American Politics and Society 53(3): 58-81.

Álvarez, Ángel. 2007. "Venezuela 2007: los motores del socialismo se alimentan con petróleo". Revista de Ciencia Política 27: 265-289.

Arriagada-Herrera, Genaro. 2006. "Petróleo y gas en América Latina: un análisis político de relaciones internacionales a partir de la política venezolana". In Documentos de Trabajo Vol. 20 Real Instituto Elcano de Estudios Internacionales y Estratégicos.

Balán, Manuel. 2013. "Polarización y medios a 30 años de democracia". Revista SAAP 7(2): 473-481.

Becerra, Martin and Gastón Mastrini. 2009. Los dueños de la palabra: acceso, estructura y concentración de los medios en la América Latina del Siglo XXI. Buenos Aires: Prometeo.

Belinche, Marcelo. 2004. Medios, política y poder: la conformación de los multimedios en la Argentina de los 90. Buenos Aires: Ediciones de periodismo y comunicación.

Bonvecchi, Alejandro and Agustina Giraudy. 2007. "Argentina: crecimiento económico y concentración del poder institucional". Revista de Ciencia Política 27: 29-42.

Bonvecchi, Alejandro and Agustina Giraudy. 2008. "Argentina: Victoria presidencial oficialista y tensiones en el esquema macroeconómico". Revista de Ciencia Política 28(1): 35-59. 
Buxton, Julia. 2005. "Venezuela's Contemporary Political Crisis in Historical Context". Bulletin of Latin American Research 24(3): 328-347.

Cannon, Barry. 2004. "Venezuela, April 2002: Coup or Popular Rebellion? The Myth of a United Venezuela". Bulletin of Latin American Research 23(3): 285-302.

Castañeda, Jorge G. 2006. “Latin America's Left Turn”. Foreign Affairs 85(3): 28-43.

Catterberg, Gabriela and Valeria Palanza. 2012. "Argentina: Dispersión de la oposición y el auge de Cristina Fernandez de Kirchner". Revista de Ciencia Política 32(1): 3-30.

Corner, John. 2007. "Media, Power and Political Culture". In Media Studies: Key Issues and Debates, edited by Eoin Devereaux. London: Sage, 211-30.

Curran, James. 2009. "Media System, Public Knowledge and Democracy: A Comparative Study". European Journal of Communication 24(1): 5-26.

D'Adamo, Orlando, Virginia García Beaudoux and Flavia Freidenberg 2000. Medios de comunicación, efectos políticos y opinión pública. Una imagen, ¿vale más que mil palabras? Buenos Aires: Editorial Belgrano.

Dasgupta, Nilanjana and Matthew Hunsinger. 2008. "The Opposite of a Great Truth is Also True: When Do Student Samples Help Versus Hurt the Scientific Study of Prejudice?" Psychological Inquiry 19(2): 90-98.

De Luca, Miguel and Andrés Malamud. 2010. “Argentina: Turbulencia económica, polarización social y realineamiento político". Revista de Ciencia Política 30(2): 173-189.

Druckman, James and Cindy Kam. 2011. "Students as Experimental Participants: A Defense of the Narrow Data Base". In Cambridge Handbook Of Experimental Political Science, edited by James Druckman, Donald Green, James H. Kuklinski and Arthur Lupia. Cambridge: Cambridge University Press, 41-57.

Ellner, Steve. 2011. "Venezuela's Social-Based Democratic Model: Innovations and Limitations". Journal of Latin American Studies 43(3): 421-449.

Ellner, Steve and Daniel Hellinger. 2003. Venezuelan Politics in the Chavez Era. London: Lynne Rienner.

Frajman, Eduardo. 2014. "Broadcasting Populist Leadership: Hugo Chávez and Aló Presidente". Journal of Latin American Studies 46(3): 501-526.

Grimmer, Justin. 2010. “A Bayesian Hierarchical Topic Model for Political Texts: Measuring Expressed Agendas in Senate Press Releases". Political Analysis 18(1): 1-35.

Grimmer, Justin and Brandon M. Stewart. 2013. "Text as Data: The Promise and Pitfalls of Automatic Content Analysis Methods for Political Texts." Political Analysis 21(3): 267-297.

Hawkins, Kirk. 2010. “Who Mobilizes? Participatory Democracy in Chávez's Bolivarian Revolution". Latin American Politics and Society 52(3): 31-66.

Hill, Chirstopher. 2003. The Changing Politics of Foreign Policy. New York: Palgrave MacMillan.

Hughes, Marie Adele and Dennis E. Garrett. 1990. "Intercoder Reliability Estimation Approaches in Marketing: A Generalizability Theory Framework for Quantitative Data". Journal of Marketing Research 27(2): 185-195.

Jones, Mark, Wonjae Hwang and Juan Pablo Micozzi. 2009. “Government and Opposition in the Argentine Congress, 1989-2007: Understanding Inter-Party Dynamics Through Roll Call Vote Analysis". Journal of Politics in Latin America 1(1): 67-96.

Kitzberger, Philip. 2009. "Las Relaciones gobierno-prensa y el giro político en América Latina". PostData 14(2): 157-181.

Kitzberger, Philip. 2010a. "Giro a la izquierda, populismo y activismo gubernamental en la esfera pública mediática en América Latina." In Poder Político y Medios de Comunicación: de la Representación Política al Reality Show, edited by Sorj Bernardo. Buenos Aires: Siglo XXI, 61-100.

Kitzberger, Philip. 2010b. "The Media Activism of Latin America's Leftist Governments: Does Ideology Matter?" GIGA working paper 151.

Lander, Edgardo. 2005. "Venezuelan Social Conflict in a Global Context". Latin American Perspectives $32(2): 20-38$.

Latinobarometro (2010) Encuesta 2010. Corporación Latinobarometro. Chile. 
Levine, Daniel. 2002. "The Decline and Fall of Democracy in Venezuela: Ten Theses". Bulletin of Latin American Research 21(2): 248-269.

Levitsky, Steven and Maria Victoria Murillo. 2008. "Argentina: From Kirchner to Kirchner". Journal of Democracy 19(2): 16-30.

López-Maya, Margarita. 2002. "Venezuela After the Caracazo: Forms of Protest in a Deinstitutionalized Context". Bulletin of Latin American Research 21(2): 199-218.

López-Maya, Margarita. 2003. “The Venezuelan Caracazo of 1989: Popular Protest and Institutional Weakness". Journal of Latin American Studies 35(1): 117-137.

López-Maya, Margarita. 2008. "Venezuela: Hugo Chávez y el bolivarianismo". Revista Venezolana de Economía y Ciencias Sociales 14(3): 55-82.

López Maya, Margarita and Luis Lander. (2010). “Venezuela 2009: En medio de dificultades avanza el modelo socialista del Presidente Chávez". Revista de Ciencia Política 30(2): 537-553.

MacRory, Robbie. 2013. "Dilemmas of Democratisation: Media Regulation and Reform in Argentina". Bulletin of Latin American Research 32(2): 178-193.

Maingon, Thais, and Friedrich Welsch. 2009. "Venezuela 2008: Hoja de Ruta Hacia el Socialismo Autoritario". Revista de Ciencia Política 29(2): 633-656.

McCombs, Maxwell. 2013. Setting the Agenda: The Mass Media and Public Opinion. Cambridge: Wiley .

McCombs, Maxwell and Donald Shaw. 1972. "The Agenda-Setting Function of Mass Media". Public Opinion Quarterly 36(2): 176-187.

MECON (2011). El Comercio Exterior Bilateral Argentina - Venezuela. Documentos de Trabajo. Ministerio de Economía y Finanzas Publicas - República Argentina. http:/ /www. mecon.gov.ar/peconomica/dnper/documentos/Venezuela_Jun2011.pdf

Mueller, John. 2002. "American Foreign Policy and Public Opinion in a New Era: Eleven Propositions". In Understanding Public Opinion, edited by Barbara Norrander and Wilcox Clyde. Washington: CQ Press, 49-72.

Mouron, Fernando, Francisco Urdinez and Janina Onuki. 2016. "Framing Effects on Foreign Policy: Experimental Evidence from Emerging Countries and the Argentine-Brazilian Rivarly". Opinião Pública 22(1): 195-218.

O'Schaughnessy, Hugh. 2007. "Media Wars in Latin America". British Journalism Review 18(3): 65-72.

Paramio, Ludolfo. 2006. "Giro a la izquierda y regreso del populismo". Nueva Sociedad 205 (Septiembre): 62-74.

Petkoff, Teodoro. 2005. Dos izquierdas. Caracas: Editorial Alfa.

Poertner, Mathias. 2011. "Venezuelan Oil Diplomacy and Voting in the U.N. General Assembly". Journal of International Service 20(Spring): 85-108.

Porter, Michael. 1980. Competitive Strategy: Techniques for Analyzing Industries and Competitors. New York: Free Press.

Proksch, Sven-Oliver and Slapin Jonathan. 2008. WORDFISH: Scaling Software for Estimating Political Positions from Texts. Version 1.3. Accessed January 2015 at http:/ /www. wordfish.org.

Puglisi, Riccardo and James Snyder. 2008. "Media Coverage of Political Scandals". Working Paper 14598. National Bureau of Economic Research.

Quinn, Kevin Burt L. Monroe, Michael Colaresi, Michael H. Crespin and Dragomir R. Radev 2010. "How to Analyze Political Attention with Minimal Assuptions and Costs". American Journal of Political Science 54(1): 209-228.

Roberts, Kenneth. 2006. "Populism, Political Conflict, and Grass-roots Organization in Latin America". Comparative Politics 38(2): 127-148.

Ruiz, Fernando. 2010. “Fronteras Móviles: Caos y Control en la Relación Entre Medios y Políticos en América Latina". In Poder politico y medios de comunicación; de la representación política al reality show, edited by Bernardo Sorj. Buenos Aires: Siglo XX, 17-60. 
Russell, Roberto and Juan Gabriel Tokatlian. 2011. "Percepciones Argentinas de Brasil: Ambivalencias y expectativas" In Brasil y América del Sur: miradas cruzadas, edited by Bernardo Sorj and Sergio Fausto. Buenos Aires: Catalogos, 281-316.

Sagarzazu, Iñaki. 2014. "Venezuela 2013: un país a dos mitades". Revista de Ciencia Política 34(1): 315-328.

Sagarzazu, Iñaki and Heike Klüver. 2017. "Coalition Governments and Party Competition: Political Communication Strategies of Coalition Parties". Political Science Research and Methods. 5(2): 333-349.

Sagarzazu, Iñaki and Fernado Mouron. 2017. The Monster Under the Bed: Under Which Conditions Chavismo Can Become a Wedge Issue. Manuscript.

Serbin, Andrés. 2006. "Cuando la limosna es grande: el caribe, Chávez y los límites de la diplomacia petrolera". Nueva Sociedad 205(septiembre): 75-91.

Slapin, Jonathan and Sven-Oliver Proksch. 2008. "A Scaling Model for Estimating Time Series Policy Positions from Texts". American Journal of Political Science 52(8): 705-722.

Soroka, Stuart. 2003. "Media, Public Opinion, and Foreign Policy". The International Journal of Press/Politics 8(1): 27-48.

United States Energy Information Administration (2017) Crude Oil-Brent-Price in US Dollars http: / / www.indexmundi.com / commodities / ?commodity=crude-oil-brent\&months $=300$

Vincent, Lucía. 2011. "La Disputa por la mediación durante el kirchnerismo en Argentina". Confines de Relaciones Internacionales y Ciencia Política 7(13): 49-81.

Vliegenthart, Rens and Stefaan Walgrave. 2008. "The Contingency of Intermedia Agenda Setting. A Longitudinal Study in Belgium". Journalism and Mass Communication Quarterly 85(4): 860-877.

Waisbord, Silvio. 2011. "Between Support and Confrontation: Civic Society, Media Reform, and Populism in Latin America". Communication, Culture E Critique 4(1): 97-117.

Wanta, Wayne Guy Golan, and Cheolhan Lee. 2004. "Agenda Setting and International News: Media Influence on Public Perceptions of Foreign Nations". Journalism \& Mass Communication Quarterly 81(2): 364-377.

Wanta, Wayne and Ghanem, Salma. 2007. "Effects of Agenda Setting". In Mass Media Effects Research: Advances Through Meta-Analysis, edited by Raymond Preiss. New York: Psychology Press, 37-51.

Zunino, Esteban and Natalia Aruguete. 2010. "La cobertura mediática del conflicto campo-gobierno. Un estudio de caso". Global Media Journal 7(14): 1-23.

Zúquete, José Pedro. 2008. "The Missionary Politics of Hugo Chávez". Latin American Politics and Society 50(1): 91-121.

Iñaki Sagarzazu holds his PhD in Political Science from the University of Houston and is currently an Assistant Professor in the Department of Political Science at Texas Tech University. Email: inaki. sagarzazu@ttu.edu

Fernando Mouron is a PhD student in the joint-degree program in International Relations between the University of São Paulo and King's College London. Email: fernando.mouron@kcl.ac.uk 


\section{APPENDIX A. ROBUSTNESS OF TEXT CLASSIFICATION}

Figure 1: Distribution of document's $\omega$ by date

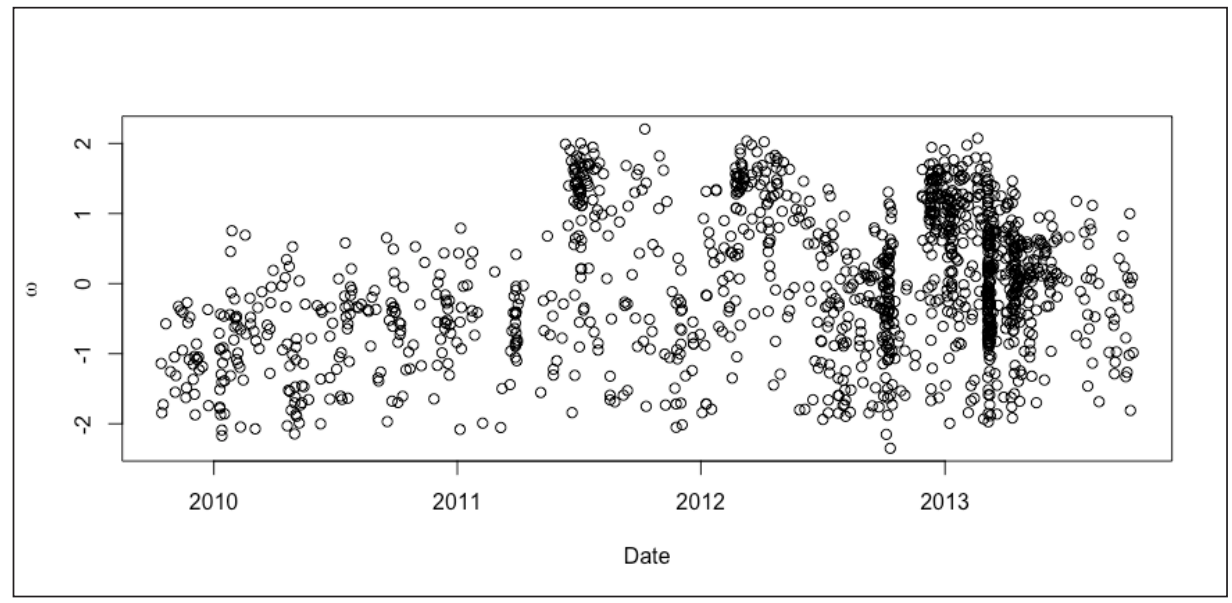

Table 1: Estimates of linear regression of $\omega$ scores on a document's date and newspaper

\begin{tabular}{ccc}
\hline Variable & Estimate & Std. Error \\
\hline Intercept & $-8.944^{* * *}$ & $(1.097)$ \\
date & $0.0005^{* * *}$ & $(0.00007)$ \\
Página 12 & $0.284^{* * *}$ & $(0.0569)$ \\
N & 1335 & \\
Adjusted R & 0.084 & \\
F & 62.38 & \\
\hline
\end{tabular}




\section{APPENDIX B. SAMPLE TEXTS}

\begin{tabular}{|c|c|c|}
\hline La Nación & 4-Sep-12 & "La Argentina y Venezuela, un paralelismo peligroso" \\
\hline \multicolumn{3}{|c|}{$\begin{array}{l}\text { "Nuestro país transita cada vez más por caminos lamentables que tienen llamativos paralelismos } \\
\text { con los de Venezuela." }\end{array}$} \\
\hline \multicolumn{3}{|c|}{ http://www.lanacion.com.ar/1505179-la-argentina-y-venezuela-un-paralelismo-peligroso } \\
\hline
\end{tabular}

\begin{tabular}{|l|c|l|}
\hline La Nación & 13-Jan-13 & Venezuela, el espejo que anticipa el futuro? \\
\hline $\begin{array}{l}\text { "Venezuela es un espejo que anticipa la Argentina del futuro. La frase se ha convertido en el } \\
\text { axioma preferido de los aterrados por el chavismo y los atemorizados por la eternización del } \\
\text { cristinismo. Como toda sentencia es un reduccionismo y como todo reduccionismo contiene una } \\
\text { dosis de verdad o de verosimilitud que lo hace creíble. Por eso, en Buenos Aires cobra relevancia } \\
\text { una vez más lo que en estos días ocurre en Caracas, donde el Tribunal Supremo de Justicia (TSJ) } \\
\text { interpreto la Constitución a la medida de Hugo Chávez ... Alguien se animara, entonces, a afir- } \\
\text { mar que con una victoria de esa naturaleza, capaz de generar un rebote de popularidad que eleve } \\
\text { la aceptación } 10 \text { o } 15 \text { puntos por sobre lo obtenido en los comicios, el kirchnerismo no intentara el } \\
\text { llamado a una consulta popular sobre la re-reelección? La Constitución no lo prevé ni lo permite, } \\
\text { pero quien se imagina al cristinismo resignándose a aceptar mansamente la letra escrita durante } \\
\text { el neoliberalismo noventista que les pone fecha de vencimiento a sus sueños”. }\end{array}$ \\
\hline http:/ / www.lanacion.com.ar/1544887-venezuela-el-espejo-que-anticipa-el-futuro \\
\hline
\end{tabular}

\begin{tabular}{|l|l|l|}
\hline La Nación & 8-Mar-13 & "Néstor, Cristina y Chávez, los trazos de una amistad inexplicable" \\
\hline $\begin{array}{l}\text { "Cuando el país ya estaba, como lo sigue estando, fuera de los mercados financieros del mundo, } \\
\text { Kirchner encontró en Chávez a un líder dispuesto a hacer negocios con la Argentina. Nada podía } \\
\text { seducir más a Kirchner que esa propuesta,... Esa decisión de Chávez es la que sigue provocando } \\
\text { los agradecimientos públicos de Cristina." }\end{array}$ \\
$\begin{array}{l}\text { http:/ / www.lanacion.com.ar/1561181-nestor-cristina-y-chavez-los-trazos-de-una-amistad- } \\
\text { inexplicable }\end{array}$ \\
\hline
\end{tabular}

\begin{tabular}{|l|c|c|}
\hline La Nación & 6-Mar-13 & De la valija de Antonini Wilson a la “embajada paralela" \\
\hline $\begin{array}{l}\text { "Cinco años después, aquel incidente abrió la senda para ahondar en la petrodiplomacia de Hugo } \\
\text { Chávez y en la llamada embajada paralela del kirchnerismo en Caracas. ... Durante aquel juicio, } \\
\text { que los gobiernos argentino y venezolano rechazaron como una maniobra política de la Casa } \\
\text { Blanca, también surgieron indicios y testimonios sobre el supuesto destino final de aquel dinero: } \\
\text { la campaña de Cristina Kirchner. Pero otros testimonios en la Argentina y en Venezuela, sin em- } \\
\text { bargo, apuntaron otra motivación: un clearing aéreo de las coimas bilaterales." }\end{array}$ \\
http://www.lanacion.com.ar/1560558-de-la-valija-de-antonini-wilson-a-la-embajada-paralela \\
\hline
\end{tabular}


\begin{tabular}{|l|l|l|}
\hline Página 12 & 23-Dec-12 & La “chavizacion" de la economía argentina
\end{tabular}

"Uno de los latiguillos que utilizan los defensores de las grandes corporaciones que se esconden bajo el eufemismo del mercado, es que cualquier intervención estatal que regule su actividad constituye un paso hacia la "chavizacion de la economía". La previa demonización mediática del presidente de Venezuela, Hugo Chávez, les permite utilizarlo como un cuco con el que espantar a empresarios".

http:/ / www.pagina12.com.ar/diario/suplementos/cash/17-6505-2012-12-23.html

\begin{tabular}{|l|l|l|}
\hline Página 12 & 9-Mar-13 & Lo que no le perdonan a Chávez \\
\hline "A Hugo Chávez no se lo perdonaron ni cuando era evidente que iba a morir. Cuando le pidió \\
a Dios un ano, cuando imploro que le diera ese tiempo. Cuando uso la metáfora de la luna llena \\
para dar una idea de qué forma, redonda, era su convicción de que Nicolas Maduro garantizaba \\
la continuidad del proyecto bolivariano. Los odiadores, dentro y fuera de Venezuela, no se lo \\
perdonaron ni le perdonaran nunca haber sido el primer presidente del mundo en rasgar el velo \\
de la gran chanchada neoliberal y haber motorizado con ideas y petróleo a una región que recién \\
cuatro o cinco años después, como resultado de la gran crisis, voto a sus compañeros de ruta, los \\
presidentes latinoamericanos que han hecho que la región, por primera vez en doscientos años, \\
crezca, pero no a cuenta de más desigualdad." \\
http://www.pagina12.com.ar/diario/contratapa/13-215412-2013-03-09.html \\
\hline
\end{tabular}




\section{APPENDIX C. SURVEY QUESTIONNAIRE}

1. ¿Cuál es su opinión del gobierno Chavista?

What is your opinion of the Chavez government

- Muy positiva Very positive

- Positiva Positive

- Negativa Negative

- Muy negativa Very negative

2. ¿ Usted considera que el gobierno argentino toma como referencia al modelo Chavista?

Do you think the Argentinian government uses the Chavista model as a reference?

- El gobierno argentino toma como referencia al modelo Chavista The Argentinian government takes as reference the Chavista model

- El gobierno argentino no toma como referencia al modelo Chavista The Argentinian government doesn't take as reference the Chavista model

3. En general, en asuntos de política $i$ usted se considera más kirchnerista u opositor?

In general, in terms of politics do you consider yourself more kirchnerist or opponent?

- $\quad$ Kirchnerista Kirchnerist

- Opositor Opponent

4. ¿ Cómo identifica este sentimiento? How do you identify this sentiment?

- Muy intenso Very intense

- $\quad$ No muy intenso Not very intense 


\section{APPENDIX D. TEXT ANALYSIS VALIDATION}

Table 1. Intercoder-reliability estimates

\begin{tabular}{ccll}
\hline Percent Agreement & $72.9 \%$ & \# Agreements & 102 \\
Scott's Pi & 0.658 & \# Disagreements & 38 \\
Cohen's Kappa & 0.658 & \# Cases & 140 \\
Krippendorff's Alpha & 0.925 & \# Decisions & 280 \\
\hline
\end{tabular}

Table 2. Regression of QTA vs. hand-coded estimates

\begin{tabular}{ccc}
\hline Variable & Estimate & Std. Error \\
\hline Intercept & 0.0299 & $(0.086)$ \\
Hand-code value & $0.1466^{* * *}$ & $(0.064)$ \\
$\mathrm{N}$ & 138 & \\
Adjusted R & 0.028 & \\
F & 5.087 & \\
\hline
\end{tabular}

Signif. levels: $0.01^{* * *} 0.05^{* *} 0.1^{*}$

Table $\mathrm{x}$. Two sample t-test with equal variance for hand-coded estimates

\begin{tabular}{lcccccc}
\hline Newspaper & Obs & Mean & Std. Err. & Std. Dev. & \multicolumn{2}{c}{$\begin{array}{c}\text { 95\% Conf. } \\
\text { Interval }\end{array}$} \\
\hline La Nación & 82 & -1.0182 & 0.1013 & 0.9177 & -1.219 & -0.816 \\
Página 12 & 54 & 1.0370 & 0.1088 & 0.8001 & 0.818 & 1.255 \\
Combined & 136 & -0.2022 & 0.1142 & 1.3324 & -0.428 & 0.023 \\
Difference & & -2.0553 & 0.1530 & & -2.357 & -1.752 \\
\hline
\end{tabular}


- 